\title{
Genetic Variability and Heritability Estimation in Water Spinach (Ipomoea aquatica Forsk.) Genotypes
}

\author{
Hina Chauhan", Jitendra Singh and Dhananjay Sharma
}

Department of Vegetable Science, College of Agriculture, Indira Gandhi Krishi

Vishwavidyalaya, Raipur- 492012, Chhattisgarh, India

*Corresponding author

\section{A B S T R A C T}

\section{Keywords}

Genetic variability,

Water spinach,

Heritability,

Genetic advance.

Article Info

Accepted:

28 August 2017

Available Online:

10 September 2017
This research was conducted at Research and Instructional Farm of Horticulture under Department of Vegetable Science, Indira Gandhi Krishi Vishwavidyalaya, Raipur, (C.G.) during the rabi season of 2015-16. All the genotypes showed wide range of variation. Phenotypic coefficient of variance $(\mathrm{PCV})$ was higher than the genotypic coefficient of variance (GCV) for all the characters. High heritability were recorded for fresh weight of 20 leaves, foliage yield, leaf length, leaf width, dry matter per cent of foliage, moisture percent and dry weight of 20 leaves. High heritability coupled with high genetic advance was observed for leaf width and green foliage yield.

\section{Introduction}

Water Spinach (Ipomoea aquatica Forsk.) is an important member of the Convolvulaceae family and it is supposed to be originated in China (Edie and Ho, 1969). Ipomoea aquatica Forsk. is an aquatic or semi aquatic tropical or sub-tropical plant, trailing or floating, herbaceous, sometimes annual or perennial, with long, hollow stem possessing large number of air passages and rooting at the nodes, found throughout India.

Leaves are elliptic or ovate-oblong, cordate; flowers are infundiuliform and have the typical open, trumpet shape of convolvulus or bindweed flowers, $2-2.5 \mathrm{~cm}$ long, white or pale purple, solitary; fruit is a capsule
(Anonymous, 1959; Edie and Ho, 1969; Gamble, 1921; Payne, 1956; Synder et al., 1981).

\section{Materials and Methods}

Twenty five genotypes of water spinach collected from different parts of the Chhattisgarh state were utilized for the present study during 2015-16 at Research and Instructional Farm of Horticulture under Department of Vegetable Science, Indira Gandhi Krishi Vishwavidyalaya, Raipur, Chhattisgarh, India. The genotypes were evaluated in RBD with three replications having a plot size of $1.8 \mathrm{~m} \times 1.8 \mathrm{~m}$. Vines 
were planted at a spacing of $30 \mathrm{~cm} \times 20 \mathrm{~cm}$. number of vines per plant, vine length $(\mathrm{m})$, inter node length $(\mathrm{cm})$, number of nodes per vine, leaf shape, leaf length $(\mathrm{cm})$, leaf width $(\mathrm{cm})$, petiole length $(\mathrm{cm})$, chlorophyll content (SPAD value), dry matter percentage of foliage $(\%)$, moisture percentage of foliage, fresh weight of 20 leaves, dry weight of 20 leaves, leaf vine ratio and number of cuttings per month were recorded on five competitive random plants from each replication. Foliage yield was calculated on the basis of observed data.

\section{Phenotypic and genotypic coefficient of} covariation

The estimates of PCV and GCV were classified as low $(<10 \%)$, moderate (10$20 \%$ ) and high (> $20 \%$ ) according to Sivasubramanian and Madhavamenon (1973). Heritability in broad sense was estimated by using the formula given by Hansen et al., (1956). The broad sense heritability estimates were classified as low $(<50 \%)$, moderate $(50$ $70 \%)$ and high $(>70 \%)$ as suggested by Robinson (1966). Expected genetic advance (GA) was calculated as per the method suggested by Johnson et al., (1955).

\section{Results and Discussion}

\section{Genotypic and phenotypic coefficient of variation}

Data presented in table 1 indicated wide range of variation for leaf width, petiole length, fresh weight of 20 leaves, dry weight of 20 leaves and green foliage yield. The range of variation was narrow for moisture percent of foliage and chlorophyll content.

Genotypic and phenotypic coefficient of variation of different characters is presented in table 1 and graphical presentation in figure 1. High magnitude of genotypic as well as phenotypic coefficient of variations were recorded for traits viz., leaf width (29.36 and 33.71), petiole length (22.51 and 27.99), fresh weight of 20 leaves (46.18 and 48.15), dry weight of 20 leaves (23.15 and 27.40) and green foliage yield (43.45 and 46.93), which suggests the substantial improvement on water spinach through selection for these traits. Moderate GCV and PCV were recorded for internode length (11.18 and 19.70), dry matter per cent of foliage (10.10 and 11.62) and leaf length (14.76 and 16.82) suggesting existence of considerable variability in the population which is important for selection criteria. Characters like number of vines per plant (17.77 and 23.64), vine length (15.76 and 23.43), leaf vine ratio (15.65 and 20.35) and number of cuttings per month (13.25 and 21.35) were having moderate GCV but high PCV while number of nodes per vine (7.56 and 16.01) was having low GCV but moderate PCV which suggests that they are sensitive to environmental fluctuations. Rest characters viz., dry matter per cent of foliage (2.31 and 2.66) and chlorophyll content (10.10 and 11.62) were having low GCV and PCV. Dash (2014) reported high magnitude of genotypic as well as phenotypic coefficient of variation for vine length and internode length in sweet potato. Chaurasiya (2012) reported high genotypic as well as phenotypic coefficient of variation for vine length and moderate genotypic as well as phenotypic coefficient of variation for fresh and dry weight of foliage.

Highest PCV and GCV were exhibited by fresh weight of 20 leaves (46.18 and 48.50) whereas lowest PCV and GCV were recorded moisture per cent of foliage (2.31 and 2.66).

1. Number of vines per plant, 2. Vine length (m), 3. Internode length $(\mathrm{cm}), 4$. Number of nodes per vine, 5. Leaf length $(\mathrm{cm}), 6$. Leaf width $(\mathrm{cm})$ 7. Petiole length $(\mathrm{cm}), 8$. Dry matter $\%$ of foliage, 9 . Moisture $\%$ of foliage, 
10. Fresh weight of 20 leaves, 11 . Dry weight of 20 leaves, 12. Leaf Vine ratio, 13. Number of cuttings/month, 14. Chlorophyll content (SPAD value), 15.Foliage yield (kg/plot)

\section{Heritability and genetic advance as per cent of mean}

Heritability governed the resemblance between parents and their progeny whereas, the genetic advance provide the knowledge about expected gain for a particular character after selection. Heritability suggests the relative role of genetic factors in expression of phenotypes and also acts as an index of transmissibility of a particular trait to its off springs. However, the knowledge of heritability alone does not help to formulate complete breeding programme, genetic advance along with heritability help to ascertain the possible genetic control for any particular trait. The nature and extent of the inherent ability of a genotype for a character is an important parameter determining the extent of improvement of any crop species. Heritability and genetic advance are the important genetic parameters for selecting a genotype that permit greater effectiveness of selection by separating out environmental influence from total variability.

The broad sense heritability estimates have been presented in table 1 and high magnitude of heritability was recorded for most of the characters. The highest heritability were recorded for fresh weight of 20 leaves $(90.6 \%)$ followed by foliage yield $(85.7 \%)$, leaf length $(77.1 \%)$, leaf width $(75.9 \%)$, dry matter per cent of foliage $(75.6 \%)$, moisture percent $(75.3 \%)$ and dry weight of 20 leaves $(71.4 \%)$. The moderate heritability was observed for petiole length $(64.6 \%)$, leaf vine ratio $(59.2 \%)$, number of vines per plant (56.5), and low heritability was observed for vine length (45.3), number of cuttings per month (38.5), internode length (32.2), number of nodes per vine (22.3) and chlorophyll content (11.7\%). Vimala and Lakshmi (1990) also reported low heritability for vine length in sweet potato.

Genetic advance as percentage of mean was observed high for fresh weight of 20 leaves $(90.64 \%)$, foliage yield $(82.80 \%)$, leaf width $(52.63 \%)$, dry weight of 20 leaves $(40.46 \%)$, petiole length $(37.35 \%)$, number of vines per plant $(27.63 \%)$, leaf length $(26.71 \%)$ leaf vine ratio $(24.75 \%)$ and vine length $(21.21 \%)$. The moderate genetic advance as percentage was observed for dry matter percent of foliage $(18.10 \%)$, number of cuttings per month (17.06\%) and internode length (13.08\%). Number of nodes per vine $(7.33 \%)$, moisture per cent of foliage (4.12) and chlorophyll content $(2.40 \%)$ showed low genetic advance as percentage of mean. Dash (2014) also found high genetic advance as percent for mean for vine length in sweet potato.

The high value of genetic advance for these traits showed that these characters are governed by additive genes and selection will be rewarding for the further improvement of such traits. Moderate genetic advance for the traits suggest that both the additive and nonadditive variance are operating in these traits and the traits exhibiting low genetic advance indicates significance of non-additive gene effects.

Heritability estimates along with genetic advance (Fig. 2) are more useful than the heritability value alone for selecting the best individual. High heritability coupled with high genetic advance was observed for leaf length, leaf width and green foliage yield indicating that most likely the heritability is due to additive gene effects and selection may be effective. Therefore, selection based on phenotypic performance of these traits would be more effective to select desirable plant type. 
Table.1 Genetic parameters of variability for foliage yield and its components in water spinach

\begin{tabular}{|c|c|c|c|c|c|c|c|c|}
\hline \multirow[t]{2}{*}{$\begin{array}{l}\text { Sr. } \\
\text { No }\end{array}$} & \multirow[t]{2}{*}{ Characters/Parameters } & \multicolumn{2}{|c|}{ Range } & \multirow[t]{2}{*}{$\begin{array}{l}\text { Mean } \\
\text { (X) }\end{array}$} & \multicolumn{2}{|c|}{$\begin{array}{l}\text { Coefficient } \\
\text { of Variation }\end{array}$} & \multirow[t]{2}{*}{$\begin{array}{l}\text { Heritability } \\
(\%)\end{array}$} & \multirow{2}{*}{$\begin{array}{l}\text { GA as } \\
\% \text { Of } \\
\text { Mean }\end{array}$} \\
\hline & & Minimum & Maximum & & $\begin{array}{l}\text { GCV } \\
(\%)\end{array}$ & $\begin{array}{l}\text { PCV } \\
(\%)\end{array}$ & & \\
\hline 01 & Number of vines/plant & 2.40 & 4.93 & 3.04 & 17.77 & 23.64 & 56.5 & 27.63 \\
\hline 02 & Vine length (m) & 0.50 & 0.97 & 0.66 & 15.76 & 23.43 & 45.3 & 21.21 \\
\hline 03 & Inter node length $(\mathrm{cm})$ & 4.71 & 8.06 & 6.04 & 11.18 & 19.70 & 32.2 & 13.08 \\
\hline 04 & Number of nodes/vine & 10.28 & 15.69 & 12.68 & 7.56 & 16.01 & 22.3 & 7.33 \\
\hline 05 & Leaf length $(\mathrm{cm})$ & 5.58 & 10.69 & 6.70 & 14.76 & 16.82 & 77.1 & 26.71 \\
\hline 06 & Leaf width $(\mathrm{cm})$ & 1.69 & 5.90 & 3.04 & 29.36 & 33.71 & 75.9 & 52.63 \\
\hline 07 & Petiole length $(\mathrm{cm})$ & 3.16 & 8.77 & 5.06 & 22.51 & 27.99 & 64.6 & 37.35 \\
\hline 08 & Dry matter $\%$ of foliage & 14.43 & 22.83 & 18.61 & 10.10 & 11.62 & 75.6 & 18.10 \\
\hline 09 & Moisture \% of foliage & 77.17 & 85.57 & 81.39 & 2.31 & 2.66 & 75.3 & 4.12 \\
\hline 10 & Fresh weight of 20 leaves & 3.80 & 26.20 & 11.76 & 46.18 & 48.50 & 90.6 & 90.64 \\
\hline 11 & Dry weight of 20 leaves & 2.00 & 5.20 & 3.83 & 23.15 & 27.40 & 71.4 & 40.46 \\
\hline 12 & Leaf vine ratio & 0.73 & 1.40 & 1.01 & 15.65 & 20.35 & 59.2 & 24.75 \\
\hline 13 & Number of cuttings/month & 2 & 3.67 & 2.93 & 13.25 & 21.35 & 38.5 & 17.06 \\
\hline 14 & $\begin{array}{l}\text { Chlorophyll content (SPAD } \\
\text { Value) }\end{array}$ & 42.77 & 57.43 & 50.81 & 3.41 & 9.98 & 11.7 & 2.40 \\
\hline 15 & Foliage yield $(\mathrm{kg} / \mathrm{plot})$ & 2.80 & 14.60 & 6.57 & 43.45 & 46.93 & 85.7 & 82.80 \\
\hline
\end{tabular}

Fig.1 Graphical presentation of GCV and PCV for foliage yield and its components

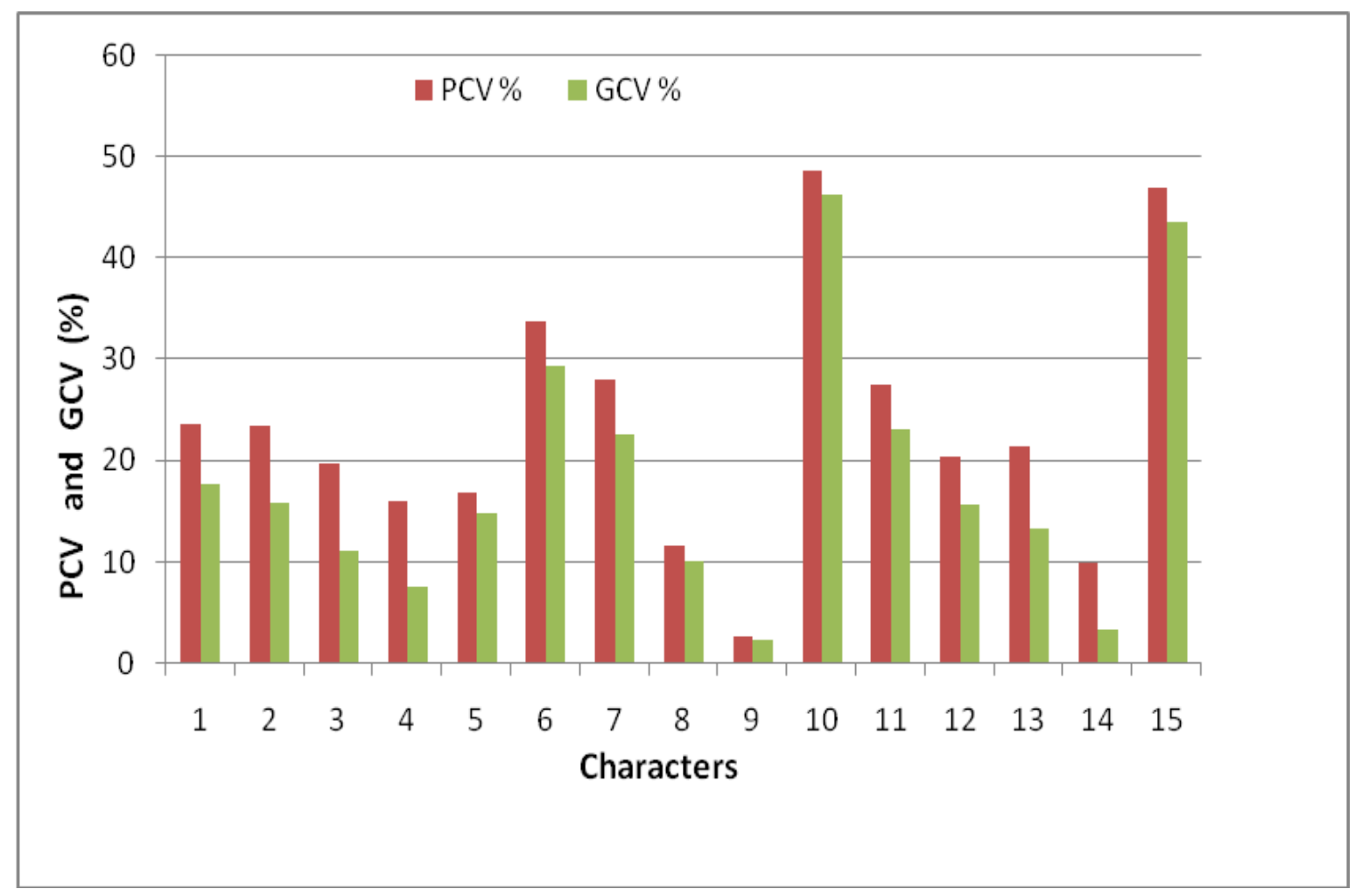


Fig. 2 Graphical presentation of heritability \% and Genetic Advance as \% of mean for green foliage yield and its components

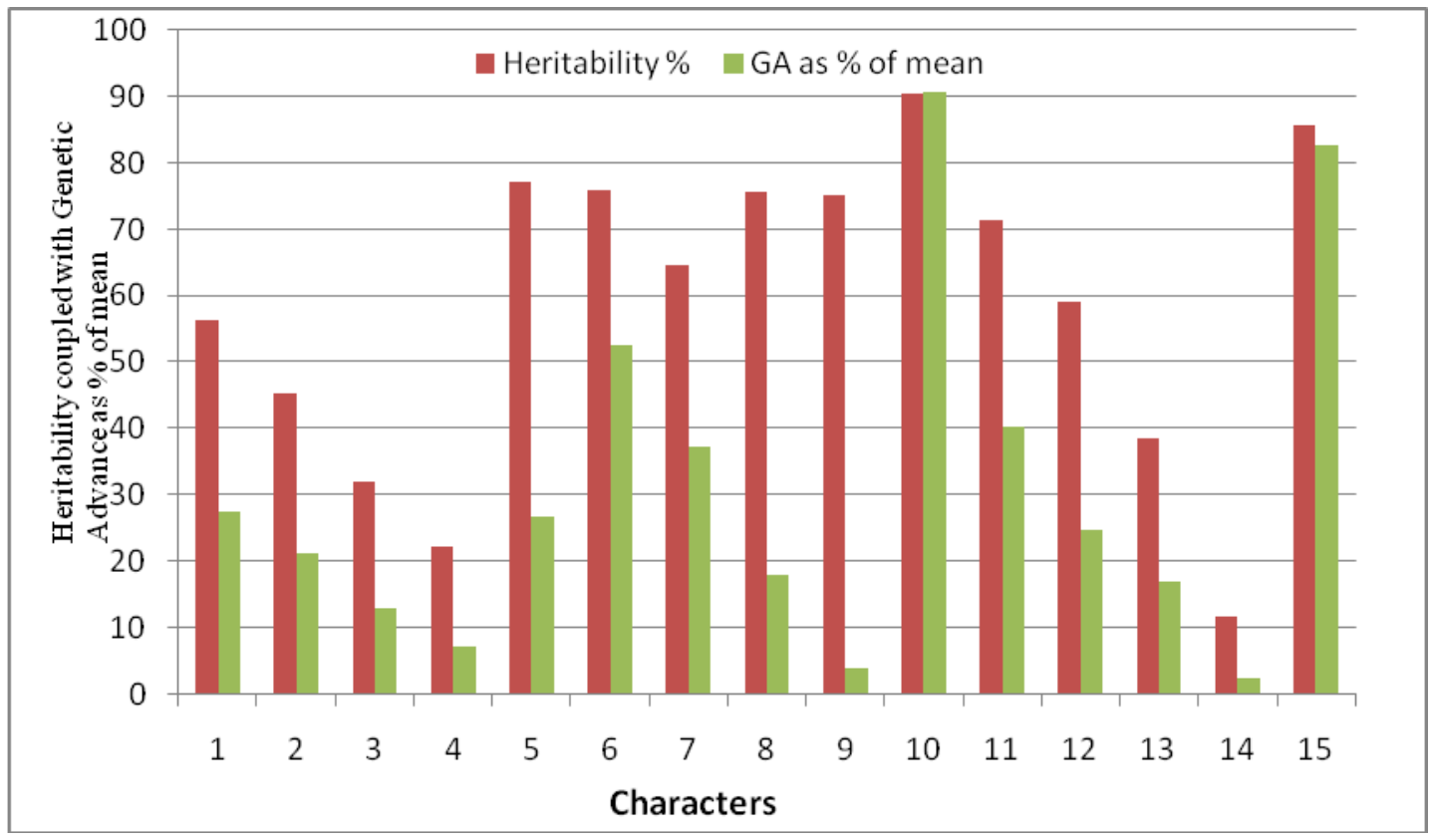

1. Number of vines per plant, 2. Vine length $(\mathrm{m}), 3$. Internode length $(\mathrm{cm}), 4$. Number of nodes per vine, 5. Leaf length $(\mathrm{cm}), 6$. Leaf width $(\mathrm{cm}) 7$. Petiole length $(\mathrm{cm}), 8$. Dry matter $\%$ of foliage, 9 . Moisture $\%$ of foliage, 10. Fresh weight of 20 leaves, 11. Dry weight of 20 leaves, 12. Leaf Vine ratio, 13. Number of cuttings/month, 14. Chlorophyll content (SPAD value), 15.Foliage yield (kg/plot)

Phenotypic coefficient of variance (PCV) was higher than the genotypic coefficient of variance $(\mathrm{GCV})$ for all the traits indicating that environmental factor was influencing their expression. Wide difference between phenotypic and genotypic coefficient of variations indicated their sensitiveness to environmental fluctuations whereas narrow difference showed less environmental interference on the expression of these traits.

The traits which showed high phenotypic and genotypic coefficient of variations are of economic importance and there is scope for improvement of these traits through selection.
Heritability and genetic advance as per cent of mean

Heritability governed the resemblance between parents and their progeny whereas, the genetic advance provide the knowledge about expected gain for a particular character after selection. Heritability suggests the relative role of genetic factors in expression of phenotypes and also acts as an index of transmissibility of a particular trait to its off springs. However, the knowledge of heritability alone does not help to formulate complete breeding programme, genetic advance along with heritability help to ascertain the possible genetic control for any particular trait. The nature and extent of the inherent ability of a genotype for a character is an important parameter determining the extent of improvement of any crop species. Heritability and genetic advance are the important genetic parameters for selecting a genotype that permit greater effectiveness of selection by separating out environmental influence from total variability. 
The broad sense heritability estimates and high magnitude of heritability was recorded for most of the characters. The highest heritability were recorded for fresh weight of 20 leaves $(90.6 \%)$ followed by foliage yield $(85.7 \%)$, leaf length $(77.1 \%)$, leaf width $(75.9 \%)$, dry matter per cent of foliage (75.6\%), moisture percent $(75.3 \%)$ and dry weight of 20 leaves $(71.4 \%)$. The moderate heritability was observed for petiole length $(64.6 \%)$, leaf vine ratio $(59.2 \%)$, number of vines per plant (56.5), and low heritability was observed for vine length (45.3), number of cuttings per month (38.5), internode length (32.2), number of nodes per vine (22.3) and chlorophyll content (11.7\%). Vimla and Lakshmi (1990) also reported low heritability for vine length in sweet potato.

Genetic advance as percentage of mean was observed high for fresh weight of 20 leaves (90.64\%), foliage yield $(82.80 \%)$, leaf width (52.63\%), dry weight of 20 leaves $(40.46 \%)$, petiole length $(37.35 \%)$, number of vines per plant $(27.63 \%)$, leaf length $(26.71 \%)$ leaf vine ratio $(24.75 \%)$ and vine length $(21.21 \%)$.

The moderate genetic advance as percentage was observed for dry matter percent of foliage $(18.10 \%)$, number of cuttings per month $(17.06 \%)$ and internode length (13.08\%). Number of nodes per vine $(7.33 \%)$, moisture per cent of foliage (4.12) and chlorophyll content $(2.40 \%)$ showed low genetic advance as percentage of mean. Dash (2014) also found high genetic advance as percent for mean for vine length in sweet potato.

The high value of genetic advance for these traits showed that these characters are governed by additive genes and selection will be rewarding for the further improvement of such traits. Moderate genetic advance for the traits suggest that both the additive and nonadditive variance are operating in these traits and the traits exhibiting low genetic advance indicates significance of non-additive gene effects.

Heritability estimates along with genetic advance (Fig. 2) are more useful than the heritability value alone for selecting the best individual. High heritability coupled with high genetic advance was observed for leaf length, leaf width and green foliage yield indicating that most likely the heritability is due to additive gene effects and selection may be effective. Therefore, selection based on phenotypic performance of these traits would be more effective to select desirable plant type.

High magnitude of genotypic as well as phenotypic coefficient of variations were recorded which, indicates prevalence of genetic variability for these traits which can be successfully utilized for genetic improvement of green foliage yield in water spinach.

Occurrence of high heritability coupled with high genetic advance for leaf length, leaf width and green foliage yield indicating that most likely the heritability is due to additive gene effects and selection may be effective for those characters towards the improvement of green yield in water spinach.

\section{Acknowledgement}

The first author expresses her heartfelt gratitude to Dr. Jitendra Singh, Professor and Head of Department of Vegetable Science, Dr. Dhananjay Sharma, Scientist, Department of Vegetable Science, Dr. S. K. Nair, Scientist, Department of Genetics and Plant Breeding and R.R. Saxena, Professor, Department of Agricultural Statistics and Social Science (L), I.G.K.V. Raipur (C.G.) India for their excellent guidance, suggestions and regular encouragement during the course of investigation. 


\section{References}

Anonymous, 1959. Wealth of India, raw materials. CSIR, New Delhi, 5:237.

Chaurasia, P. C., 2012. Combining ability analysis for yield and quality attributes in sweet potato [Ipomoea Batatas (L.) Lam.]. Ph. D. Thesis, IGAU, Raipur.

Dash, S. P., 2014. Evaluation of sweet potato [Ipomoea batatas (L.) Lam.] Genotypes for yield and processing traits. M.Sc. (Ag.) Thesis, IGAU, Raipur.

Edie, H. H., and Ho, B. W. C. 1969. Ipomoea aquatica as a vegetable crop in Hong Kong. Econ. Bot., 23:32-36.

Gamble, J. S., 1921. Flora of Presidency of Madras, India.

Payne, W. J. 1956. Ipomoea reptans Poir. A useful tropical fodder plant. Trop.
Agric. Trin., 33:302-305.

Robinson, H.F., Comstock, R.E. and Harvey, P.H. 1951. Genotypic and phenotypic correlation in corn and their implication in selection. Agron. J., 43: 262-67

Sivasubramanian, J., And Madhavamenon, P. 1973. Genotypic and phenotypic variability in rice. Madras Agric. J., 12: 15-16.

Synder, G. H., Morton, J. F. and Genung, W. G., 1981. Trials of Ipomoea aquatica, nutritious vegetable with high protein and nitrate extraction potential. Proc. Fla. State Hortic. Soc., 94:230-235.

Vimala, B., and Lakshmi, K. R. 1990. Heritability estimates in sweet potato (Ipomoea batatas (L.) Lam.). J. Root Crops, 16: 35-38.

\section{How to cite this article:}

Hina Chauhan, Jitendra Singh and Dhananjay Sharma. 2017. Genetic Variability and Heritability Estimation in Water Spinach (Ipomoea aquatica Forsk.) Genotypes. Int.J.Curr.Microbiol.App.Sci. 6(9): 3018-3024. doi: https://doi.org/10.20546/ijcmas.2017.609.370 